\title{
A NEW THRIPS DAMAGING ORCHIDS IN THE WEST INDIES.
}

By C. B. Williams, M.A., F.E.S.

The thrips described below has recently been a source of considerable damage to orchids grown for ornamental purposes in Trinidad, West Indies. Up to the present it has not been found on wild orchids and it is possible that it is not indigenous to this island. A large number of orchids are brought over from Venezuela and it may have been imported with them from that country.

\section{Order THYSANOPTERA. Family THRIPIDAE.}

Physothrips xanthius, sp. nov.

․ Measurements. -Total length, about $0.9 \mathrm{~mm}$. Head, length, $0.076 \mathrm{~mm}$, width, 0.132 mm.; prothorax, length, $0.088 \mathrm{~mm}$., width, $0.160 \mathrm{~mm}$.; pterothorax,

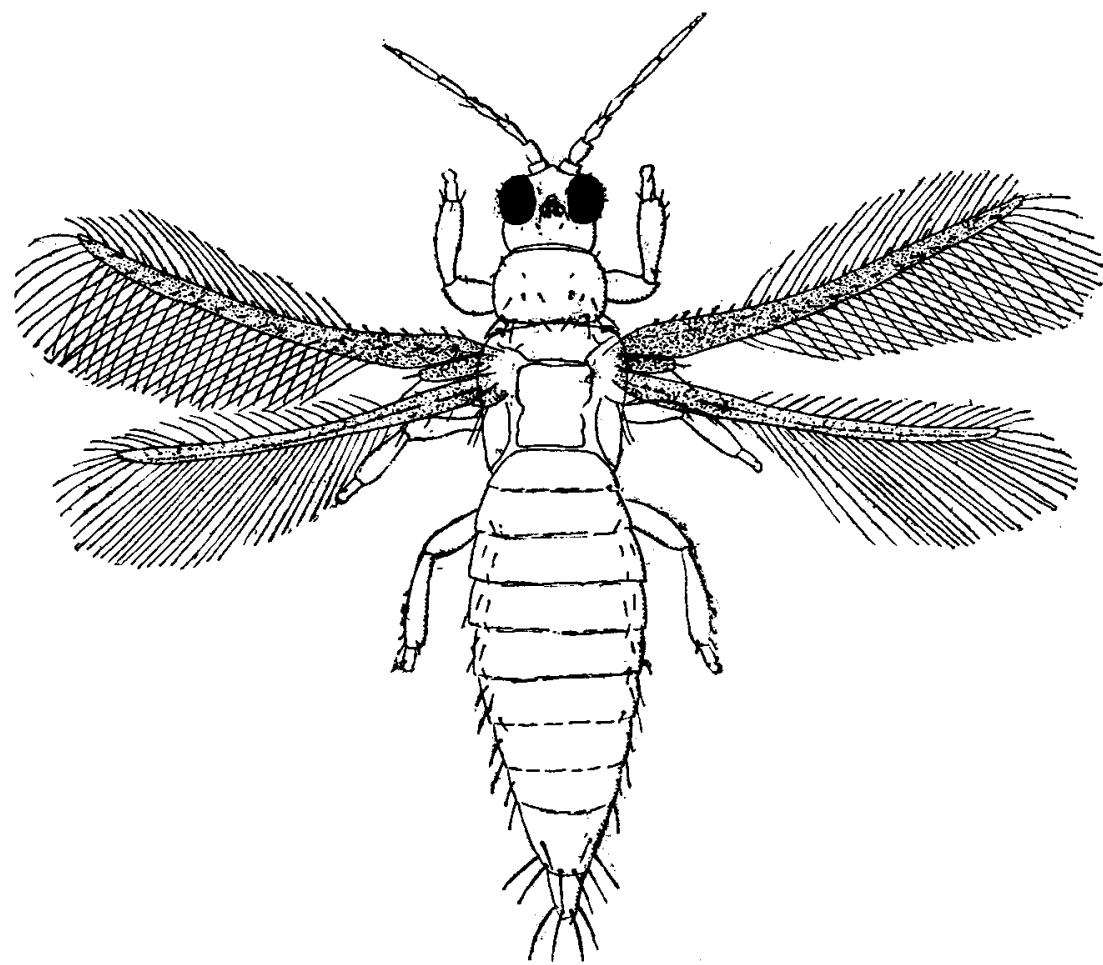

greatest length, $0.180 \mathrm{~mm}$., width, $0.200 \mathrm{~mm}$. ; abdomen, width, about $0.180 \mathrm{~mm}$.; wing, length, $0.580 \mathrm{~mm}$., width of middle, $0.028 \mathrm{~mm}$.

$\begin{array}{llcccccccr}\text { Antennae } & \ldots & 1 & 2 & 3 & 4 & 5 & 6 & 7 & 8 \\ \text { length }(\mu) & \ldots & 22 & 31 & 34 & 48 & 40 & 52 & 9 & 14 \\ \text { width }(\mu) & \ldots & 29 & 24 & 18 & 17 & 15 & 13 & 6 & 4\end{array}$

Total length of antenna, $0.290 \mathrm{~mm}$. 
Coloration.-Body and legs almost uniformly pale yellow, the fore part of the head very slightly darker. Antennae a little darker brown, except for the bases of the third and fourth segments, which are very pale. Eyes black; ocellar pigment reddish orange. Wings brown, distinctly darker than the body, with the central portion of the outer half a little paler than the margins.

Head not quite twice as broad as long; the cheeks not arched. Eyes large, very slightly projecting; distance between the eyes greater than the width of the eye; distance from the eye to the back of the head about half the length of the eye. Ocelli on a level with the middle of the eye, the three forming an obtuse triangle; the posterior pair about twice as far apart as they are distant from the margin of the eye; the anterior ocellus directed forward. Ocellar and post-ocular spines and a few smaller ones on the vertex, pale and indistinct; the ocellar spines arise from the sides of the ocellar triangle. Mouth-cone bluntly rounded, reaching about two-thirds across the prosternum. Maxillary palps short, three-segmented; the basal segment short, the two others subequal. Labial palps slender, apparently two-segmented. Antennae eight-segmented, relatively long, being three and a half times the length of the head : the first segment short and broad; the second barrel-shaped; the third with a distinct pedicel and narrowed to a slight neck at the apex; the fourth widest at about half its length, but narrowing rapidly apically to a long neck; the fifth with a distinct ring joint at its base, truncate apically; the sixth long and gradually tapering; the eighth half as long again as the seventh. Forked trichomes on the third segment dorsally and the fourth ventrally, that on the third segment reaching just beyond the base of the fourth, and that on the fourth reaching to about one-third the length of the fifth segment. Prothorax about one and two-thirds as wide as long, all angles rounded. Two pale spines at each hind angle of the pronotum each about half as long as the dorsal length of the pronotum; short spines at the front angles, other small spines very inconspicuous. Pterothorax normal; at the front angle there is, more or less distinct, a small double tooth-like projection in front of the base of the fore wing, one portion of this is long and slender, the other short and broad. Legs normal. Wings fully developed; veins on the fore wing almost invisible, only indicated by the position of the bases of the spines. On the costa there are 20-21 spines; on the fore vein two groups of 3 near the base and 2 near the apex; on the hind vein 11-13. The anterior fringe commences just distal to the base of the hind vein; the posterior fringe extends a little further towards the base of the wing. Hind wings paler than the fore wings, with a rather broad dark, central vein distinct almost to the apex of the wing. The minute setae on both wings are dark and conspicuous. Abdomen normal ; the ninth segment longer than the tenth; spines on the last two segments pale, those on the ninth segment about as long as the tenth segment, those on the tenth segment a little longer. No trace of comb-like structure on the hind margin of the eighth tergite.

б unknown.

Described from about a dozen females collected on Cattleya orchids in Port of Spain, Trinidad, on various dates during 1915 and 1916 by $F$. W. Urich and C. B. Williams.

Type in the author's collection. 
A NEW THRIPS DAMAGING ORCHIDS IN THE WEST INDIES.

This species is chiefly recognisable by its yellow body colour, brown fore wings and the relatively long antennae.

The larvae and pupae are found with the adults on the upper surfaces of the leaves, particularly near the mid rib and towards the base of the leaf. They cause injury by piercing the surface, resulting in brownish spots or patches on the leaves. In severe cases the plant may be entirely killed. 